\title{
Los nuevos prometeos : La imagen positiva de la ciencia y el progreso en la poesía española del siglo XIX (1868-1900) / Marta Palenque
}

Indice $(40429 c 3 e-45 b 0-42 c d-9 b a c-b 21 e 9 d 8 e 96 c a \cdot h t m l)$

$\nabla$

\section{Los nuevos prometeos: La imagen positiva de la ciencia y el progreso en la poesía española del siglo XIX (1868-1900)}

Marta Palenque

El siglo XIX respira el mito del progreso ${ }^{1}$ (40429c3e-45b0-42cd9bac-b21e9d8e96ca_1.html\#N_1_), sin duda su idea más característica, lo que se advierte en la revolución experimentada en el campo de la ciencia y la técnica, en un nuevo paisaje delimitado por vías férreas, grandes canales (como los de Suez y Panamá) y toda esa arquitectura del hierro que hoy nos parece tan sintomática de aquella época. Es fácil abrir una de sus revistas, periódicos o libros de poesía y encontrarse con una composición en verso en torno a los conceptos de ciencia o progreso, o que celebre la maravilla de concretos adelantos técnicos y científicos: los globos aerostáticos, los hilos telegráfico y telefónico, el submarino, el ferrocarril, el automóvil, los descubrimientos, gracias al microscopio y a nuevos reactivos, del bacilo de la tuberculosis (o de Koch) y la penicilina de Pasteur, etc. (etcétera) A los ojos del hombre de este siglo todos los campos del saber humano están cambiando de forma decisiva y revolucionaria, al igual que las nuevas máquinas alteran su concepto de tiempo y espacio, y tornan distinta su relación con el medio. Los escritores han heredado de sus antecesores ilustrados su optimismo científico: si Manuel José Quintana cantó a la vacuna y a la invención de la imprenta, el poeta de esta centuria, animado por la ascensión imparable de la ciencia y el maquinismo, llega a expresiones 
ditirámbicas, a veces de embeleso y arrobo, ante los prodigios de su siglo, de los que se siente partícipe, protagonista. Las Exposiciones Universales dan a conocer a un público más amplio las glorias de este avance imparable hacia un futuro de bienestar y felicidad.

Sin embargo, y como se sabe, esta fe en el progreso tuvo grandes fisuras y dio lugar a numerosas polémicas entre aquellos que lo entendieron de manera distinta o que desconfiaron de la realidad de ese futuro esperanzador, que no llega a las clases sociales más deprimidas. Para unos, el progreso alcanza cotas de símbolo casi místico frente al deterioro del catolicismo, es la nueva religión de la modernidad, de la que se pretende una nueva reorganización social de la que no se escapa la misma imagen de la divinidad; para otros, es una amenaza sin remedio, un cataclismo inevitable. Se libra ahora una singular batalla con la naturaleza, a la que se quiere domeñar o vencer. Por supuesto, los sectores católicos se muestran conservadores y condenan esta valoración extrema, en su juicio, frente al orden natural. Pero, además, también los grupos más revolucionarios y marginales van a rechazar el mito del progreso al mismo tiempo que condenan los valores de la sociedad burguesa y desconfían abiertamente de sus promesas de un futuro mejor, que no encuentran en las calles ni en los suburbios de las grandes ciudades. Esta polémica adquiere mayor virulencia a finales de siglo en coincidencia con el auge del maquinismo, cuando muchos artistas en toda Europa ofrecen un espejo muy distinto del progreso científico y tecnológico, y cantan a los seres marginales, a los abandonados en ese proyecto de mejora social, que se juzga fracasado. Los escritores y artistas se mueven entre la ambigüedad de la alabanza al progreso de la edad moderna y su desencanto ante los resultados del industrialismo (por ejemplo, ambas facetas en Baudelaire), lo que motiva en algunos círculos intelectuales una ola de anti-industrialismo entre 1895 y 1905 que intenta, en parte, recuperar la faceta moral del progreso (mejorar la vida del hombre) y rechaza la visión de una humanidad guiada por las máquinas ${ }^{2}$ (40429c3e-45b0-42cd-9bac-b21e9d8e96ca_1.html\#N_2_).

En España, la inquietud posterior a la revolución de 1868 alentó esta polémica, que tiene una especial significación en el campo de la poesía. Los románticos habían intentado, sin éxito, encontrar un eje armónico en la relación entre poesía y ciencia como única forma de llegar a la fusión de hombre y naturaleza (Argullol 1990: 22-28). En la era del Realismo persisten los ecos de su angustia, como ejemplifica el leopardiano Joaquín M. ${ }^{a}$ Bartrina. También autores como Gaspar Núñez de Arce y Emilio Ferrari -con este último la polémica se funde con la antimodernistacreían que el avance tecnológico conllevaba, de forma inextricable, el fin del misterio, del idealismo, de la misma belleza, el acabamiento de los temas y formas hasta ahora usados en la tradición, y que con ellos habría de morir la poesía. Otros (Ventura Ruiz Aguilera, Manuel del Palacio, Melchor de Palau) defendieron actitudes más conciliadoras y confiaron en un progreso coincidente en todos los campos del saber y en una armonización entre poesía y ciencia. Tanto Palacio como Palau ejemplifican el extremo más optimista de esta discusión al entender que, lejos de desaparecer, la poesía encontrará nuevos temas de inspiración en los avances científicos 
(aunque Palacio oscile entre la defensa y la condena). Melchor de Palau llega a proponer una «poesía científica», una poesía fresca y moderna, fruto de la colaboración entre ambas disciplinas, que ofrecería la realidad surgida de la paulatina revolución tecnológica. No es mi intención aquí entrar en los extremos teóricos de esta polémica, que, sin embargo, tiene que formar parte del marco de mi reflexión ${ }^{3}$ (40429c3e-45b0-42cd-9bac-b21e9d8e96ca_1.html\#N_3_). Mi proyecto es otro: quiero ofrecer una serie de testimonios del tratamiento positivo que recibe el tema de la ciencia y el progreso en la poesía de la segunda mitad del XIX, analizar cómo aparecen retratados o referidos los inventores y científicos, de qué forma se ensalzan sus descubrimientos y máquinas, y cuáles son las imágenes, el léxico y el ritmo de estas composiciones. Los posibles ejemplos son numerosos, por lo que partiré de una necesaria selección.

En estas composiciones en torno a la ciencia y el progreso de la humanidad los poetas retoman la imagen mítica de Prometeo, tan querida para sus antecesores románticos, aunque ahora, en una revisión realizada bajo la óptica del Positivismo, se subraye la estrecha relación entre la fuerza de estos nuevos Prometeos con el poder creciente del progreso tecnológico. Como Prometeos sienten haber alcanzado el calor, la luz, la velocidad, que parecían privativos de los dioses gracias a su trabajo, al que, dentro de este mismo contexto de fervoroso amor a la ciencia, dedican composiciones que recuerdan el arduo esfuerzo que ha realizado la humanidad para ganar este límite. Como Prometeos han llegado a penetrar lo oculto e imposible hasta el momento, lo reservado al misterio y que parecía quedar limitado al poder divino, y han formado un nuevo hombre, marcando un hito insoslayable en la historia de la humanidad. Es esta, pues, una visión racional y mecanicista del símbolo, frente al concepto vital y orgánico preferido por los románticos, que hacen de Prometeo la figura central de su mito del Anima Mundi. Entre el hombre y la naturaleza ahora está la máquina.

Pero retomar la imagen de Prometeo en este ensayo no es gratuito en ningún sentido, porque, para cantar esta era de progreso y gloria científica, los poetas del período realista utilizan de forma reiterada como base de sus alabanzas y condenas la mitología clásica, y realizan continuas comparaciones con dioses y gigantes de la antigüedad, que vierten en los moldes de la oda o el himno; de tal manera que la poesía que celebra los inicios de la modernidad tecnológica y científica se caracteriza por su preferencia por formas del pasado. En algunos versos se afirma que la poesía actual nace de la superación del mito, ahora hecho realidad tangible por las conquistas científicas, pero se afirma en un tono épico coincidente o, al menos, de tonalidad rancia. Sólo en el léxico y en algunas expresiones puntuales se observan novedades, por otra parte necesarias para nombrar la nueva realidad científica.

\section{El «siglo de la ciencia»}


Los poetas de la segunda mitad del XIX afirmaron que la poesía debía reflejar su época y sus inquietudes, y condenaron el alejamiento romántico y su gusto por el pasado y la evasión legendaria. Este es uno de los postulados básicos de la Poética (1883) de Ramón de Campoamor.

«Los artistas deben encarnarse en su tiempo por medio de afecciones literarias y vínculos históricos, asociando a sus asuntos los modos de decir y de pensar hijos de las circunstancias. Cada siglo tiene su corriente de ideas que le son propias, y que, al vestirse, toman el traje de moda de su tiempo»,

y concluye:

«No es posible vivir en un tiempo y respirar en otro».

También Gaspar Núñez de Arce (1891a; 1891b: 5 y 6-7; 1892: 9) defiende la necesidad de que la poesía hable de los problemas del presente; desde las mismas trincheras, el poeta debe cantar el nuevo mundo surgido de los cambios políticos, filosóficos y científicos, reflejando la crisis que han ocasionado.

Para otros tantos poetas (que irán apareciendo a lo largo de este ensayo) la ciencia, como parte crucial de la flamante realidad, se convierte en emblema y símbolo, en tema y recurso, en elemento indispensable, al fin, para la comprensión del «espíritu del siglo» (Ruiz Aguilera s. a. (sin año): IX-X). Los testimonios aportan casi un retrato de la sociedad que vivió aquellos cambios y que los interpretó de dispar manera en virtud de su ideología.

\section{Odas e himnos al siglo XIX}


Enlazando con la retórica ilustrada, el poeta del siglo XIX gusta de magnificar la fuerza del pensamiento humano que, como asegura Carlos Fernández-Shaw (1883: 31), gana en altura al mismo Himalaya («Al Himalaya. Soneto»). Los versos aluden de forma reiterada y pronto tópica al nuevo «siglo de la ciencia» y recuerdan la necesaria armonización que debe lograrse entre ciencia y arte, lo que termina convirtiéndose en un recurso repetido en todas aquellas composiciones que aluden al pensamiento, la inteligencia humana, la libertad de los pueblos, etc. (etcétera)

El poeta decimonónico, consciente del trascendental papel que le cabe como transmisor de las ideas y sentimientos de su tiempo, construye odas e himnos donde celebra con orgullo los adelantos de su edad, su avance en el camino hacia el progreso de la humanidad. En la senda de la poesía cívica a lo Quintana y Núñez de Arce, Manuel Reina (22 enero 1881: 54-55) convocaba a los poetas del siglo a cantar esta nueva realidad:

«Cantor, despierta: el siglo te reclama

con tu trompa sonora

al palenque te llama del pensamiento.

[...]

Cantor, despierta: en tu valiente lira

suena el clarín de guerra

del soberbio cañón el estampido;

las grandes convulsiones de la tierra;

el golpe y el crujido

de la muda piqueta destructora,

y el sonoro silbido

de la rauda y gentil locomotora.

Asiste a los Congresos y Ateneos,

y respira su atmósfera encendida;

contempla en los modernos coliseos

la horrorosa batalla de la vida.

Baja al taller, de inspiración tesoro,

donde entonan las máquinas sublimes

un cántico de oro $[\ldots]$... 
Ciencia y técnica son ingredientes que forman parte consustancial del ser de la nueva centuria, como se lee en «Al siglo XIX. Oda», de Narciso Campillo (1879: 115-116); «El siglo XIX», de Antonio Fernández Grilo (1879: 103-108 ${ }^{5} \quad$ (40429c3e-45b0-42cd9bac-b21e9d8e96ca_1.html\#N_5_)); «Mi siglo. Himno», de Miguel Gutiérrez (15 febrero 1887: 106) y «Al siglo XIX», de José Lamarque de Novoa (1895: 81-89). Todos estos autores coinciden en una entonación épica, elocuente e hiperbólica de los prodigios científicos del siglo, y ensalzan el poder del pensamiento humano, que ha logrado someter a la naturaleza misma, obteniendo un mayor bienestar para la sociedad y una mejor distribución del trabajo. El orgullo y el asombro del hombre de la época son evidentes en estos poemas, que cantan la extraordinaria realidad surgida de los cambios científicos y las nuevas sensaciones que ahora experimentan: pueden trasladarse a velocidades inimaginables, cruzar montes, atravesar canales, hacer el día en la noche, comunicarse a largas distancias, cruzando mares y continentes, encerrar una imagen en una fotografía gracias a la luz, volver a oír voces y canciones previamente grabadas en un cilindro... El hombre parece poderlo todo gracias a una ciencia calificada de «bienhechora» $\mathrm{y}$ «excelsa».

En su oda Narciso Campillo sale al paso de los insultos de aquellos que sólo miran con aprecio el pasado y califica al siglo de «colosal», «inmortal», «portentoso», «el mayor que vio la historia»; una permanente sucesión de milagros y triunfos de la inteligencia humana que han permitido progresar al hombre sobre los cimientos construidos en otras épocas: 


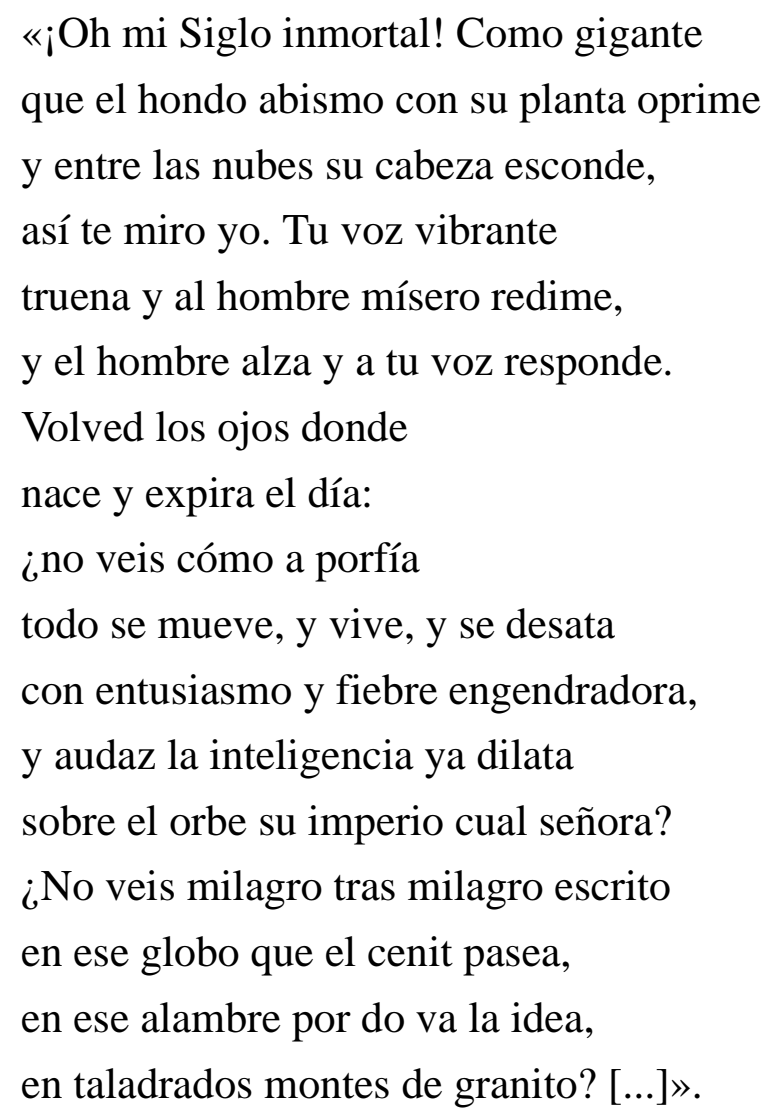

También Antonio Fernández Grilo muestra al lector la realidad de este magnífico esfuerzo y, con continuas llamadas de atención, le apela a sentir, ver y oír las nuevas maravillas, acentuando los efectos acústicos y visuales. Sobre todas se alza el ferrocarril, voz de este «siglo del vapor», descrito como un «Titán magnífico», un «monstruo», que «silba y serpentea», cuya velocidad increíble es recreada a través del ritmo del verso, las exclamaciones y la selección de comparaciones y términos relacionados con el campo semántico de la velocidad: «ligero como el rayo desprendido», «por los llanos rápido se agita», «con hirviente fragor se precipita», «cual gigante torbellino»... La fuerza de la máquina se equipara con la de la naturaleza, a la que llega a superar: «No hay peñascos que turben su camino / ni huracán que le estorbe en su carrera». Es la prueba del poder del siglo, que ha alcanzado a construir tan imponente monstruo, que reúne la fuerza de fieras y rocas. Junto al tren figuran el telégrafo, la fotografía, los nuevos barcos de vapor, el globo aerostático, la luz de gas, la prensa; todos son prodigios de la nueva edad. El apóstrofe final testimonia el orgullo que sienten estos poetas, testigos y protagonistas de un nuevo fiat lux: 
«Despierta, patria mía;

despierta y ciñe inquebrantables lazos

al siglo hermoso que al Edén te guía

aprisionada en sus robustos brazos.

Mira del arte las lozanas flores

envolverse en el cielo de la idea

entre blancas guirnaldas de vapores;

oye el viento que llora

repitiendo en el mundo los cantares

de la hirviente y fugaz locomotora;

escucha el son del piélago bravío,

y verás la palabra detenida

del negro cable en el cañón sombrío;

mira el pino, fantasma de la sierra,

bordando los abiertos horizontes,

cortando las distancias de la tierra

con las redes de alambre donde encierra

la palabra que vuela por los montes.

Contempla tu magnífica grandeza,

alza tu frente de laurel ceñida,

y verás que has nacido cuando empieza

sobre la tierra a palpitar la vida».

Por su parte, Miguel Gutiérrez compone un exultante himno a la centuria en el que, en coincidencia con la «poesía científica» de Melchor de Palau, parte de la poesía clásica y recurre a la mitología para expresar las nuevas verdades. En versos heptasílabos con marcado ritmo a causa de la tendencia a la rima esdrújula y aguda, los hombres son los héroes modernos y llegan aun más allá que los antiguos. El tiempo presente es la realización de los mitos soñados por los antiguos: 


\author{
«Resuene ya mi cántico \\ al siglo en que he nacido; \\ mi voz no es la del pájaro \\ que oculto ve su nido \\ de ruinas melancólicas \\ en lóbrego rincón. [...] \\ ¡Oh bellas metamórfosis [sic] \\ de la gentil poesía! \\ Verdades sois, no fábulas, \\ que Ovidio os soñaría \\ de edad futura símbolos, \\ signos de su esplendor. \\ Ya en el peñón del Cáucaso \\ no gime Prometeo; \\ el fuego que a los númenes \\ robó, ya es su trofeo, \\ y anima el grande espíritu \\ de un siglo redentor».
}

Doblegado ante la ciencia, el gigante Encelado sufre una metamorfosis y, ciñendo una «armadura férrea», se convierte en locomotora («corcel flamígero») y, luego, en submarino, irritando al padre Océano al invadir su reino; junto a los «templos místicos» de antaño ahora se yerguen «las negras fábricas / donde el vapor ondula»; Mercurio rompe su caduceo, inútil ante la maravilla del telégrafo («Por nervios mil eléctricos / rayo fugaz serpea, / y en alas del relámpago / va la triunfal idea [...]»); incluso la parca Átropos es vencida por el mágico fonógrafo, que permite recobrar la voz de un fallecido («Dormido en caja ebúrnea / nuestro postrer acento, / espera en ecos póstumos / feliz resurrección. / No entera al negro túmulo / desciende ya la vida: / cual a conjuro mágico, / latiendo estremecida, / de entre cenizas áridas / saldrá la humana voz»). Aun más, ahora el hombre puede coronar hazañas que estuvieron vedadas a los héroes de la Antiguiedad: puede volar «por cima de las águilas» gracias al globo y descender a lo más profundo de la tierra iluminado por las nuevas lámparas. El microscopio y los avances en la ciencia química le permiten conocer un nuevo mundo microscópico y atisba el mismo origen de la vida ( «Y seres hay sinnúmero, / bajo la ley divina, / en los sutiles átomos / de gota cristalina, / y en los inmensos piélagos / del cerco terrenal. [...] / Y los primeros gérmenes / de tierras y de cielos / de la materia cósmica / desgarran ya los velos, / mostrando los orígenes / del ser y del no ser»). El saber humano descifra misterios antiguos, como los jeroglíficos, y anima al hombre a hollar nuevos continentes. Todos estos cambios, índices del progreso humano, conducen para Miguel Gutiérrez a la libertad y 
el amor entre los hombres.

El tono épico se reitera en «Al siglo XIX», de José Lamarque de Novoa, que empieza con un apóstrofe:

«iSalve, rey de los siglos! Voladora

la Fama extiende tu renombre al viento,

y absorto al abarcarlo el pensamiento

sólo sabe admirar...».

Para Lamarque este es un siglo de esplendor absoluto, en el que han brillado de forma singular todas las artes y las letras, y junto a ellas la ciencia:

«Cómo la Ciencia inerte

yacer pudiera, cuando altiva y fuerte

ya descollaba en anteriores siglos

de absurdas opiniones vencedora,

segura se adelanta, tremolando

del progreso la enseña bienhechora;

y a la asombrada humanidad mostrando

de mil inventos la vivaz centella,

rastros de luz fulgente

va en su marcha triunfal tras sí dejando,

cual del espacio peregrina estrella».

$(82-83)$

$\mathrm{Su}$ discurso lírico acerca a los lectores a los principales descubrimientos y nombra a los creadores de este «siglo prepotente»: 


\author{
«Ya el admirable invento \\ de Stephenson contempla, que más tarde, \\ del mundo asombro, en fraternal abrazo \\ unirá a las naciones; \\ ora el de Morse, que aduna la palabra \\ al eléctrico flúido [sic], \\ y veloz la transmite, en dulce lazo \\ estrechando a los pueblos: \\ ya, en fin, el del insigne \\ Edison, que aprisiona \\ la humana voz y, audaz, la reproduce \\ a su potente voluntad sumisa...».
}

Este elogio a la ciencia es, sin embargo, sólo la primera parte del poema, claramente dividido en tres secciones: el primero es la alabanza del presente marcado por la gloria de la ciencia; en el segundo surge una visión negativa del futuro ante el peligro del socialismo, nuevo monstruo nacido de las entrañas del progreso («¿Oculto llevas en tu mismo seno / letífero veneno / que habrá de darte vergonzosa muerte?», 88); y el último cierra con una invocación esperanzada: aún hay tiempo para modificar ese futuro si el hombre no olvida a Dios.

\title{
Los nuevos Prometeos: Científicos e inventores
}

Entre el conjunto anónimo de seres humanos, sin duda son los inventores los que ostentan con mayor significación el título de nuevos Prometeos de una moderna mitología, de nuevos héroes de la epopeya tecnológica de la sociedad industrial del siglo XIX, que, como indica Agustí Nieto-Galán (2001: 15), erige una especie de «panteón laico de los dioses de la ciencia y la técnica» en el que brillan los nombres de Newton, Edison, Watt, Darwin, Curie, Marconi, Morse, Lesseps y otros tantos. Repasar sus biografías es, muchas veces, acercarse a una galería de mártires de la religión de la ciencia y la tecnología. Las calles y paseos españoles (como los de otros países) guardan recuerdo de estos hombres, y los pabellones de las Exposiciones Universales nos han dejado cumplido testimonio de su gloria en relieves y leyendas tallados en sus frisos y 
muros. En el mito del progreso se inscribe también el mito del inventor, que, investido de un estatus similar al de políticos y militares, figura de forma relevante en la estatuaria civil. La valoración del genio y de la individualidad creadora en el Romanticismo contribuyó de forma decisiva a encumbrar en el imaginario colectivo, junto a escritores y artistas, a científicos e inventores $^{6}$ (40429c3e-45b0-42cd-9bac-b21e9d8e96ca_1.html\#N_6_).

En la oda ya citada de José Lamarque de Novoa cada uno de los adelantos técnicos de la humanidad son victorias frente a la naturaleza y la ignorancia conseguidas con el trabajo y el estudio de los valientes científicos: el barco de vapor del ingeniero inglés Robert Fulton le ha permitido vencer a los «revueltos mares», dominando vientos y olas; con pasmo contempla la locomotora de George Stephenson, que ha unido las naciones con caminos de hierro, al igual que Samuel Morse lo hizo con los cables del telégrafo; o el «insigne» Thomas Alva Edison, admirado en su tiempo como una especie de mago (lo que recreó Villiers de L'Isle Adam en su novela $L a$ Eva futura), al que, entre otros hallazgos, se deben las primeras impresiones acústicas en cilindros de metal, sometiendo a la misma voz humana; y a Ferdinand-Marie Lesseps, que llevó a cabo la «gigantesca empresa» de los canales de Suez y Panamá. Pero los sabios que asombran al siglo son muchos más:

\author{
«[...] En vano intenta, \\ fatigada la mente, \\ ¡oh siglo portentoso! de tus sabios \\ enumerar las múltiples creaciones: \\ Ellas, surgiendo en rápida creciente, \\ como raudal de desbordado río, \\ pasmo serán de cien generaciones. \\ Nada pudo negarse al poderío \\ de su indómito afán $[\ldots .$. »».
}

(Lamarque de Novoa 1895: 83-84)

En otros tantos poemas se extreman los cantos de gloria a estos bravos soldados de la ciencia que, con «entereza y constancia»-como indica Lamarque de Lesseps-, se enfrentan no sólo a las fuerzas de la naturaleza sino a los hombres ignorantes que frenan sus colosales empresas. Cada nuevo descubrimiento les impulsa a continuar su lucha: 


\author{
$\ll[\ldots]$ a cada triunfo se alza en su conciencia \\ de luchas el deseo, \\ cual, si la guerra estalla, \\ el caudillo a las lides avezado \\ viste el marcial arreo \\ y se apresta de nuevo a la batalla».
}

(Idem: 85)

Los inventores son calificados de visionarios y soñadores, cualidades que subrayan su hermandad con los artistas: todos anhelan alcanzar un nuevo mundo, una realidad renovada, aunque con diferentes medios. Así se lee en el poema «A Murillo» de José Velarde, fechado en 1882 (Velarde 1886: 114):

«Sueñe el artista, pues, con noble empeño:

el pensamiento humano,

ni aun de las ciencias penetró en lo arcano

sin las alas quiméricas del sueño.

Sueña Franklín [sic], y atrae las centellas;

sueña Watt, y el vapor se hace fecundo;

sueña Newton, y fija las estrellas;

sueña Colón, y se engrandece el mundo».

El mismo José Velarde (idem: 125-132), en uno de los numerosos poemas dedicados a «El Trabajo» de aquellos años (éste fechado en 1882), abunda en la evolución paralela del progreso en todos los campos del saber. Velarde compone una suerte de cosmogonía, recurso frecuente en la retórica del tema del progreso pues permite la lógica narración del crecimiento del pensamiento humano, gracias a cuyo esfuerzo el hombre ha ido transformando su realidad, y menciona a Newton, Galileo, Gutenberg, Franklin y Colón, junto a Homero, Fidias, Orfeo, Velázquez y Murillo: 


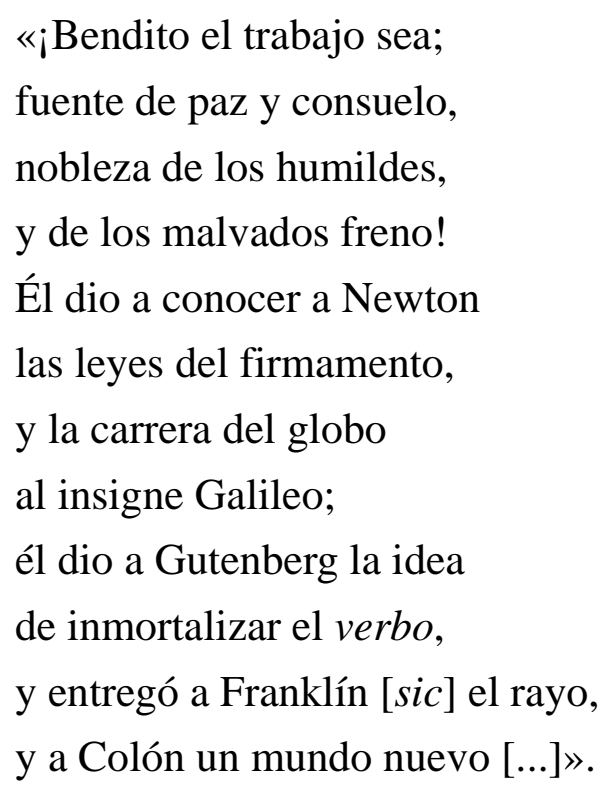

Pero los científicos no sólo permiten relacionarse de manera distinta con la realidad y la transforman, sino que descubren nuevos mundos, como recuerda José María Gutiérrez de Alba (16 abril 1896: s. p. (sin página)) en el poema «El mundo microscópico. Al eminente sabio $\mathrm{Mr}$. (míster) Pasteur». El poeta intenta transmitir en sus versos el asombro y la sorpresa que causan al hombre de la época los espectaculares descubrimientos en el campo de la bacteriología, que, junto a los decisivos avances en anatomía e histología, y en gran medida gracias al desarrollo de la medicina experimental llevada a cabo en el Positivismo, revolucionan el mundo de la medicina. Gutiérrez de Alba se centra en los hallazgos de Louis Pasteur («de las ciencias coloso») y le describe con rasgos de visionario y mago, a veces casi un santo; en cualquier caso un ser especial, pues a muy pocos seres humanos se les ha otorgado el poder de llevar la luz a las tinieblas del conocimiento: 


\author{
«Tu espíritu, entre sombras avanzando, \\ salvó al fin las tinieblas de la duda; \\ y la verdad buscando \\ entre el bullir de la materia muda, \\ descubrió dilatados horizontes. \\ Con mano firme y ardoroso anhelo \\ alzó una extremidad del denso velo \\ con que de las miradas codiciosas \\ el poder creador tiene escondidas \\ y en profundos arcanos sumergidas \\ sus obras portentosas; \\ y comprendió que cuanto el orbe llena \\ es forzoso eslabón de una cadena».
}

Sigue refiriendo de forma detenida los progresos paulatinos de este «sabio eminente», cuya figura crece hasta límites sobrehumanos cuando se le presenta como vencedor de gérmenes terribles, de enfermedades que actuaban de forma traidora:
«A tu ilustre memoria
siempre acompañarán las bendiciones
de todas las naciones,
y quedará en la historia,
como ejemplo inmortal, noble y honroso,
el que haciendo a los males cruda guerra,
derramar supo el bien sobre la tierra».

Junto a Pasteur el poeta recuerda a otros hombres de ciencia ilustres: Jeuner, Koch y el español Ferrant.

No menos interés y atracción despertaron en España los experimentos de Narciso Monturiol, inventor del «Ictíneo» (mencionado, por ejemplo, en «La poesía y la ciencia», de Palau, s. a. (sin año): 22), y, años más tarde, los de Isaac Peral, que perfeccionó el submarino. Los modernos telescopios habían permitido conocer las lejanas estrellas y el globo volar más alto que las mismas 
águilas, en comparación repetida en esta poesía; el microscopio alcanzar el origen de la vida; ahora se rinden las profundidades marinas. La extremeña Carolina Coronado (1993, II: 755) rinde tributo a Peral en un número extraordinario de la revista La Idea, el 15 de agosto de 1890, con un soneto en el que se equipara su hazaña con la realizada por Cristóbal Colón. El orgullo patrio de la autora se muestra en su recuerdo de la intrepidez española, que antaño permitió descubrir nuevas tierras; Colón y Peral son signos de ese valor:
«Descubríos, señores de los mares.
Bajad la frente saludando a España, que la gloria de nuevo la acompaña con su corte de genios seculares.
Alumbrado por sacros luminares, lleve Colón sobre la mar su hazaña; hoy de la mar bajo la misma entraña navegan nuestros dioses titulares».

También Luis Pérez Barzana dedicó un largo poema a Peral, titulado A Isaac Peral: España con honra (1889), tras las pruebas satisfactorias de su submarino realizadas en el Arsenal de La Carraca en San Fernando (Cádiz), en 1888 y 1889. La composición, además de ser una loa hiperbólica al inventor, se convierte en un alegato patriótico en el que se advierte a las restantes naciones acerca del poder bélico español, ahora demostrado por la nueva máquina de guerra. La hazaña culminada por Peral enlaza con las de Pelayo, el Cid, Colón, Cortés, Murillo y Cervantes, y demuestra la pujanza de la ciencia española, desmintiendo las críticas injuriosas de los extranjeros. Así termina el poema:

«¡Aún no han muerto las glorias nacionales!

¡Aún no está su valor prostituido!

¡Aún hay un español que se alza erguido

para sacarla del pesar profundo!

¡Aún por ella vigila el león despierto!

¡La raza de sus héroes aún no ha muerto!

¡Aún puede España conquistar un mundo!». 
El retrato de Peral no difiere de los rasgos expuestos hasta ahora: genio modesto y audaz que se atreve a intentar lo imposible, que lucha de forma titánica hasta ver hecha realidad su idea. Su submarino es calificado como «cetáceo de acero», «monstruo raro, de corteza ruda», y, continuando la imagen zoológica, es descrito de la siguiente forma en los versos más novedosos del texto:

«Venas de tubos forman su mecanismo,

hilos de alambre su nerviosa masa,

fluido es la sangre que veloz repasa

la red de su intrincado mecanismo $[\ldots] »$.

\section{La máquina y la poesía}

Las máquinas y los descubrimientos científicos fascinaron a los hombres del siglo XIX y esto es algo que evidencia todo el arte decimonónico.

La estatuaria civil se encargó no sólo de inmortalizar a los inventores y sabios sino que, además, se ocupó de encarnar plásticamente los valores de la ciencia y el progreso a través de alegorías que, en coincidencia con los poemas y otras obras artísticas, recurrieron a la mitología como fuente iconográfica. Muchas veces estas alegorías figuran en grupos escultóricos dedicados a reyes, políticos y mecenas (el dedicado a «Alfonso XII» y «Bravo Murillo», en Madrid; a «Joan Güell i Ferrer»y al «Marqués de Comillas», en Barcelona; al «Marqués de Guadiaro», en Málaga; etc. (etcétera)). Carlos Reyero ha localizado y revisado estas alegorías en las que junto al Progreso figuran el Comercio, la Agricultura y la Industria, las Letras, las Artes, el Trabajo y la Ciencia, o el Ferrocarril y el Gas, etc. (etcétera) Pegasos, jóvenes portadores de antorchas y figuras femeninas de regusto clásico representan tales conceptos o realidades materiales. La sociedad industrial difundía, así, el valor edificante de los principales símbolos de su nueva fe (Reyero 1999: 119-121 y 408). El mismo entusiasmo se advierte en la prensa, cuyos títulos y cabeceras rinden tributo al nuevo orden científico en títulos como el romántico El Vapor, o los posteriores El Ferrocarril o El Progreso. La cabecera de La Ilustración Española y Americana es un buen ejemplo iconográfico 
de lo dicho, al reunir los principales símbolos de la sociedad industrial, en cuyo crecimiento también colaboran la prensa y los adelantos técnicos de los que, en el terreno de la impresión y, sobre todo, el grabado, esta revista es pionera en España ${ }^{7}$ (40429c3e-45b0-42cd9bac-b21e9d8e96ca_1.html\#N_7_). Ésta y otras revistas ilustradas ofrecen con asiduidad imágenes de estas nuevas realidades tecnológicas, con mucha frecuencia de aplicación militar (cañones, torpedos, barcos y aeroplanos...).

Como ejemplo de este entusiasmo, las máquinas se convierten en tema central de composiciones poéticas que insisten en el tratamiento de la ciencia y la técnica ya visto y permiten comprobar no sólo el orgullo y el embeleso, sino también el miedo ante su creciente fuerza y poder. Aunque la entonación enfática y declamatoria siga siendo dominante, aparecen otras marcas de la poesía del período.

En este punto la fecundidad del tren como tema retórico, como alegoría del progreso, es sobresaliente y se presta a todas las notas, humorísticas o épicas. La imagen del «tren de la libertad» se repite en los ensayos de los historiadores, filósofos y economistas del XIX (Proudhon hablaba de la idea del progreso como el ferrocarril de la libertad) y pasa a la literatura ${ }^{8}(40429 \mathrm{c} 3 \mathrm{e}-$ 45b0-42cd-9bac-b21e9d8e96ca_1.html\#N_8_). Los nuevos caminos de hierro supusieron en España una profunda transformación del sistema de transportes; las vías férreas se extendieron a lo largo del siglo a paso acelerado, sustituyendo a la tracción animal. No extraña que se convierta en el tema central de muchas composiciones o que sea el contexto o la anécdota que da sentido al asunto. Los ejemplos son numerosos, empezando por uno de los poemas más conocidos de la segunda mitad del XIX: «El tren expreso», pequeño poema en tres cantos de Ramón de Campoamor, que el poeta dedicó a su amigo y compañero en las lides literarias, y además ingeniero de caminos, José de Echegaray. Este romance sobre raíles que sabían de memoria tantas lectoras aparece enmarcado en el trepidar y el humo del ferrocarril, convertido en «fiera encadenada» que, una vez libre, se torna en «sierpe que sale de su nido» y luego en «león con melena de centellas». El viaje en tren que aquí se narra describe las sensaciones del viajero: la velocidad, el rápido paso de terrenos y accidentes geográficos, las luces que permiten entrever el vagón en la oscuridad...; en definitiva, hay una especial atracción ante la máquina: es monstruo y fiera, pero también belleza y prodigio fruto de la feliz invención humana. En las composiciones ya utilizadas más arriba se advierten expresiones similares.

El tren cambia el mismo concepto del viaje y permite la contemplación de un paisaje distinto, al mismo tiempo que lo transforma, pues pasa a formar parte de la nueva realidad de la era del Realismo (Litvak 1991: 181-224). La velocidad del nuevo medio de transporte es el referente bien de poemas amables y humorísticos, bien de ambientes de ansiedad y pesadilla, y se convierte en metáfora para materializar la ansiedad, el miedo o el mismo destino. Por ejemplo, José López Silva (1898: 175-179) se burla en «Impresiones de viaje» de los modernos y ágiles trenes que 
incorporan vagones de «lispin car» (sleeping car); José Selgas (1882: 119-121), en «Tren esprés [sic]», usa el tren como referente para describir una relación amorosa muy fugaz y pronto olvidada; y Ricardo Gil (1931: 73-74), en «El puente», lo convierte en un símbolo onírico de consecuencias fatales. En un período marcado por los conflictos bélicos, el tren es también el vehículo que conduce a la guerra y a veces pareciera que su fuerza y ruido son adelantos de la fiereza del futuro enfrentamiento («Ruge la locomotora / con rugido de pantera [...]» («jA la guerra!», Blanco-Belmonte 1906: 135-137).

En un siglo en el que la poesía tiene un valor social y circunstancial tan destacado, no extrañan los poemas relativos a inauguraciones de vías férreas que se convierten en encendidos elogios de la ciencia humana. El tono épico y la retórica grandilocuente son también característicos de estas composiciones, muchas destinadas a ser leídas en los mismos actos de inauguración, como en el caso de «Versos improvisados con motivo de la inauguración del ferrocarril de Almansa a Valencia» (19 noviembre 1859), de Vicente W. Querol (1985: 187-189), quien llegaría a secretario y luego subdirector de la compañía de ferrocarriles M. Z. A. De nuevo la locomotora es un monstruo colosal, una fiera salvaje dominada por el hombre:

\author{
«Miradle: rebramando el monstruo fiero \\ sueltas al viento sus nevadas crines, \\ con ímpetu altanero \\ salva de Edeta [Valencia] alegres confines. \\ Ya por los valles cóncavos retumba \\ su estridente rugido; \\ ya en las llanuras castellanas zumba, \\ y entre el fragor sonoro \\ de sus miembros de hierro, álzase erguido \\ el hombre y rige sus tirantes de oro».
}

$(187-88)$

El tren es el mensajero de «un siglo de gigantes», «dios de la industria» y nuevo Mercurio que unirá pueblos y razas, «vencedor» de una naturaleza que abre sus entrañas y horada sus montes ( «arcos de gloria») para permitir su paso. La máquina redime y libera al hombre, que ahora esclaviza a las fuerzas de la naturaleza gracias a la técnica: 


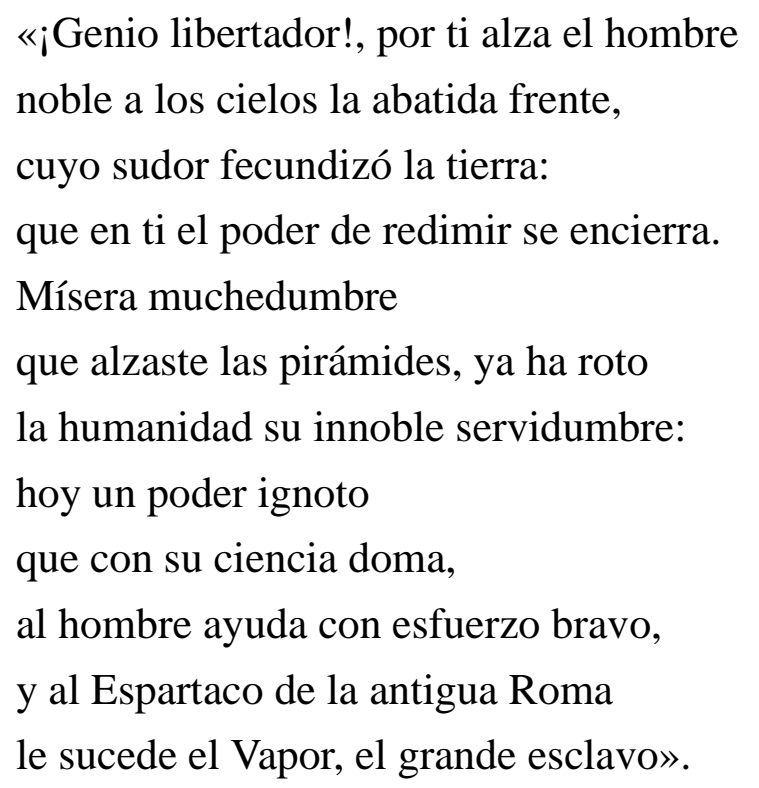

Tal vez este poema de Querol se incluyó en un álbum conmemorativo, como en el caso de otros tantos acontecimientos similares en la España de aquellas fechas. Recuerda Josefa Martínez Romero (1987: 40) que la inauguración de la línea férrea que unía Linares con Almería fue «el acontecimiento social y político más relevante de la Almería de 1899». En el acto de inauguración, el 12 de marzo de 1899, se celebraron varios festejos y, entre ellos, una velada literaria en la que los poetas almerienses celebraron con sus versos tan fausto acontecimiento, luego recogidos en la revista literaria titulada, y viene al caso, El Ferrocarril. En el mismo número se incluyó «Progreso!» de Narciso Díaz de Escovar (luego en Díaz de Escovar s. a. (sin año): 132-136), optimista himno en el que la locomotora, el telégrafo y la luz, emblemas de la nueva religión del progreso y símbolos de la fuerza del pensamiento humano, vencen la ignorancia y el fanatismo. Lo mismo se observa en otras tantas inauguraciones a lo largo de la Península9 (40429c3e-45b0-42cd9bac-b21e9d8e96ca_1.html\#N_9_).

Es evidente que hay un uso patriótico del progreso y la ciencia en estos actos, que aprovecharían los gobernantes de turno para dar muestras de su competencia y vendrían acompañados de no pocas placas conmemorativas en las que figurarían sus nombres. El progreso y la ciencia se hermanan siempre con la libertad, la paz y la prosperidad del país y de la región donde ocurre el evento.

Otras inauguraciones de obras públicas extasiaron a los hombres de la época. El trabajo hercúleo que suponía construir canales y túneles convertía al hombre en un ser excepcional gracias 
a la ayuda de la técnica y mereció alabanzas como las de Manuel del Palacio (25 noviembre 1871: 574-575): «El túnel de Mont-Cenis»; Gaspar Núñez de Arce (s. a. (sin año): 51-94): «Inauguración del canal del Ebro»; Manuel Fernández Ruano (1874): Oda al Canal de Suez, o Alpha y Omega. Trilogía, de José María Gutiérrez de Alba (1890). Esta última es una extensa cosmogonía que parece influida por las utopías socialistas y narra la génesis y el fin de la vida sobre el planeta. Está dividida en tres partes, con los siguientes títulos: «El canal interoceánico. Oda dedicada al Genio del ingenio Mr. (míster) Ferdinand de Lesseps» (fechada en Bogotá, 7 septiembre 1879), «El hombre» y «La luna» (Madrid, mayo y octubre de 1885). La moraleja del poema es que el hombre debe utilizar su tecnología para el bien de la humanidad por encima de fines bélicos, de provecho económico egoísta o de simple diversión.

Pasando a otros descubrimientos y hallazgos técnicos, y de nuevo en el terreno de la locomoción, el vapor se aplicó a otros medios como el automóvil, pero, en la década de los setenta, el uso del petróleo determinó su suerte definitiva y preparó su evolución hasta los vehículos actuales. En su descripción poética los autores repiten la misma imaginería usada para cantar al tren, como en «El automóvil», de Blanco-Belmonte (8 octubre 1903: 219), cuya fecha explica su avance hacia el Modernismo:

\footnotetext{
«Rugiendo con rugir de tigre fiero

es un monstruo que avanza, señorea

y corre a la victoria sin pelea, como bridón de charolado acero.

El genio poderoso y altanero

le dio la fuerza que fecunda y crea, y así va el automóvil: es la idea que marcha libre por el orbe entero. Dejad paso a la máquina atrevida, que brilla cual los bélicos troqueles y alcanza lauros en la lid reñida: ¡que el automóvil, rey de los corceles, es la locomotora redimida que ha roto las cadenas de los rieles!».
}

Como se encargaron de recordar los escritores costumbristas, el siglo del vapor se convirtió pronto en el de la electricidad ${ }^{10}$ (40429c3e-45b0-42cd-9bac-b21e9d8e96ca_1.html\#N_10_). La «chispa de la idea» se convierte ahora en el nuevo tópico de la sociedad industrial y, junto al tren, 
tal vez sea el telégrafo el hallazgo técnico más alabado en la poesía. Su valor para conciliar la voluntad de las naciones, para estrechar lazos de fraternidad, es la cualidad más ensalzada. En las odas al siglo mencionadas antes los poetas cantaban este poder del telégrafo y así puede leerse en algunos de los fragmentos citados. En «A un poste telegráfico» Marcos Rafael Blanco-Belmonte (1906: 193) canta al ser natural ahora transformado con fines científicos muy nobles, y recoge el sentir de la centuria:

«iEras ayer muy grande! Tu ramaje

ostentaba su pompa en el camino, como señor que marca su destino al pueblo que le rinde vasallaje. En tu copa, penacho del boscaje, cantó el jilguero su cantar divino; tu sombra dio consuelo al peregrino, tu tronco, freno al huracán salvaje. Y al mirarte sin hojas, sin verdores, sin nidos y sin pájaros cantores, tu grandeza se ensancha y señorea. Que al erguirte en el monte o en el llano... ¡eres el sostén del pensamiento humano y arde en tu sien la chispa de la idea!».

Otros inventos relacionados con la comunicación y la voz como el teléfono y el fonógrafo debieron de parecer tan mágicos y sobrenaturales que los poetas insisten en conectarlos con el Más Allá. Así se entiende en la comparación que establece Juan José Herranz (28 febrero 1878: 151) en «El teléfono»: 

«La voz no se extingue

en la tumba helada,

del hombre que llora,

del hombre que canta,

sobre el aparato

los ecos resbalan,

dejando unos surcos

en la cera blanda,

que lo que hoy recogen

repiten mañana.

Y pasan los años,

y cuando descansa

en la caja grande

aquel que cantaba,

se busca llorando

la pequeña caja,

que encierra el cilindro

que los ecos guarda,

y la rueda empieza,

la uniforme marcha,

y vuelven a oírse

notas y palabras,

iy la sombra del muerto querido

resucita y habla! [...]».

Jackson Veyán describe de forma minuciosa el funcionamiento de la máquina cuando declara su pavor por este regreso de los difuntos (y es una de las escasas descripciones directas del objeto que se localiza en esta poesía): 


\author{
«A mí me dan frío \\ los cilindros que hablan, \\ cuando la corriente \\ misteriosa y vaga \\ invade un momento \\ la aguja metálica, \\ $\mathrm{y}$ adquiriendo vida \\ las pequeñas rayas, \\ al contacto del aire repiten \\ notas y palabras!».
}

Ya en otro texto, similar estupefacción despierta la máquina fotográfica:

(Fernández Grilo 22 diciembre 1879: 399)

pero aquí la comparación con la pintura es inevitable y a veces pierde en el cotejo, porque, como en la composición anterior, la máquina atrapa la imagen física, pero el alma necesita del pincel para ser retratada.

Desde la Great Exhibition of the Works of Industry of All Nations celebrada en Londres, en 1851, las Exposiciones Universales se constituyeron como el escaparate de los productos nacidos de la Revolución Industrial y atrajeron a un elevado número de visitantes, nacionales y extranjeros. Manuel Ortiz de Pinedo (15 noviembre 1878: 286-287) cifra en verso el valor que estas reuniones encierran para el hombre de la época en su poema titulado «La Exposición Universal de París», que califica como canto al progreso y la ciencia, dilatado y extenso muestrario de las principales conquistas del hombre en los distintos campos del saber: 


\author{
«Allí, alcázar gigante circundado \\ de césped y de flores, \\ donde la luz se quiebra fulgurante \\ en sus lucientes vidrios de colores, \\ ofrece en el recinto dilatado \\ de sus anchas, inmensas galerías, \\ suntuoso alojamiento, \\ a cuanto el pensamiento \\ puede abarcar en ordenada historia, \\ desde el tosco relieve, carcomido, \\ que en los remotos días \\ atestiguo la gloria \\ de un hecho esclarecido, \\ hasta el postrer invento \\ que con ardor se afana \\ por transmitir, vibrando en su sonido, \\ de siglo en siglo la palabra humana».
}

Allí se reúnen las naciones y, orgullosas, revelan las novedades de su pensamiento. Entre todas, en una visión de futuro, destaca Norteamérica, que demuestra su interés por la tecnología doméstica, dando señales de su adelanto con respecto a la vieja Europa («[...] proclamando su lema utilitario, / la máquina potente / para fraguar el hielo y la ingeniosa / de coser y bordar, en el Certamen / presenta la República orgullosa [...]»). Ortiz de Pinedo describe el interés del público por las nuevas máquinas, a las que admira con la misma sensibilidad que antaño a las grandes obras de arte. La técnica no sólo aporta máquinas útiles sino, además, continuos prodigios «de sin igual belleza»; es la ley de los nuevos tiempos:

$\ll[\ldots]$ inmensa muchedumbre

busca do quier la máquina, afanosa

bajo la tersa, colosal techumbre,

guardando su mirada cariñosa

para admirar los monstruos animados

que el problema resuelve palpitante

de abaratar la vida en los mercados». 


\section{La fábula y la poesía didáctica}

La fábula y la poesía didáctica, de tan amplio cultivo en el siglo, fueron cauces idóneos para transmitir las maravillas de la ciencia y para enseñar las bondades de la tecnología. Un ejemplo de ello es la colección de Fábulas en verso originales de Concepción Arenal (1851; en la reedición de 1854 se señala que sirven «para la enseñanza en las escuelas de instrucción primaria»), que dedica varios textos a cubrir este fin ${ }^{11}$ (40429c3e-45b0-42cd-9bac-b21e9d8e96ca_2.html\#N_11_). La misma finalidad didáctica tiene el libro La Poesía Moderna de José Fola Igúrbide (1898), subtitulado «Libro escrito expresamente para los niños que aspiran a ser hombres». Al frente del conjunto, el autor coloca su declaración de intenciones en verso y, en la línea de Melchor de Palau, afirma que la poesía debe seguir el curso de los tiempos y cantar los nuevos temas que la ciencia aporta e invita a los poetas a servirse de los cambios materiales y a abandonar recursos antiguos y culturalistas, dejando a un lado las leyendas medievales maravillosas y los cantos al mar, al lujo y al amor, para cantar a la ciencia y loar al obrero («ese mártir del trabajo»): «Educa con Arte al Niño / injertando en su conciencia / los gérmenes de la Ciencia / con las mieles del cariño» (9). La filiación progresista del autor asoma en su proclamación de este «nuevo oficio» del poeta moderno. Los poemas que siguen son un tratado de física y ciencias de la naturaleza (junto a otros de enseñanza moral) en los que la figura de Dios es permanente: Él es el sentido último de las leyes que explica a los niños en «El lago y la piedrecilla», «La gota de rocío», «La oración de la tarde» (acerca del movimiento del globo terrestre), «El globo de papel» y «Los cuatro elementos». Usando un lenguaje sencillo muy distinto de la retórica de la ciencia decimonónica, describe a los niños las mismas cualidades humanas a partir del léxico de la ciencia; por ejemplo, el esfuerzo de la voluntad, en el poema de igual nombre, es asociado, sucesivamente, a una máquina, un motor, y un dique de contención.

Las revistas y libros de lectura y enseñanza dirigidos a los niños ofrecen otros testimonios de este aspecto singular de la relación entre poesía y ciencia.

\section{De la «Poesía Científica» de Melchor de Palau al «fin de siglo»}

En el planteamiento optimista de la ciencia en la segunda mitad del siglo XIX el proyecto del 
poeta, ingeniero y catedrático de Geología y Paleontología catalán Melchor de Palau supone un hito insoslayable. Palau inició, en 1881, la publicación de las que llamó Verdades poéticas, traducidas a varios idiomas y reeditadas hasta alcanzar la sexta edición. Además, en 1908, en su discurso de ingreso en la Real Academia Española de la Lengua, disertó sobre el tema «La Ciencia como fuente de inspiración poética», verdadero manifiesto cuyo contenido conciliador en lo referente a la polémica entre la ciencia y la poesía ya ha sido mencionado. Frente a los que condenan la introducción de temas y voces científicas, él apuesta por renovar las fuentes de inspiración, abandonando los viejos y gastados recursos expresivos para beber directamente de las verdades de la ciencia. Palau pretende escribir una «poesía científica» que muestre la nueva realidad del hombre al filo del siglo XX, lo que plasma en sus poemas «A la Geología», «El rayo», «Al Polo Ártico», «Al carbón de piedra», «Al faro eléctrico de Nueva York», «A la locomotora» $\mathrm{y}$, continuando a Quintana, «A la imprenta», entre otros. Todos son un canto de admiración hacia el poder del pensamiento humano, capaz de gobernar las fuerzas de la naturaleza y aplicarlas a la industria, en cuyo brillante futuro, paralelo al del arte, cree el poeta. Su fe en este mundo futuro le convirtió en el vate idóneo para componer el «Himno a la Exposición Universal de Barcelona» en 1888 (incluido en Palau 1905).

El poeta-ingeniero confiaba en la renovación de la poesía gracias a los nuevos temas y vocabulario que aportaba la ciencia, lo que resume en su oda «La Poesía y la Ciencia», donde la encarnación de la Ciencia anima a la Poesía a trocar los motivos antiguos (representados por los dioses mitológicos de la Antigüedad) por los del presente. La loa a los mártires de la ciencia ( «herederos del don de los milagros») y a sus descubrimientos debe ocupar un lugar central en la obra de los poetas futuros, a decir de Palau, quien en sus poemas habla del submarino, el telégrafo, el fonógrafo, la fotografía, el tren..., de la Biología, Química, Botánica... Sus composiciones incorporan notas que recuerdan a los lectores teorías científicas y el nombre de sabios en las más diversas materias de los que parten las imágenes poéticas: la biogenética de Haeckel, el radiómetro de Crookes, etc. (etcétera), aunque se encarga de subrayar que sus pretensiones no son didácticas y que, por el contrario, sus poemas presuponen el conocimiento por parte del lector de las hipótesis científicas que exponen. En algún caso, incluso, augura las posibilidades de algunos hallazgos científicos: así, en «Glorias efímeras del artista dramático» (1880) confiaba en que, tras la máquina fotográfica y el fonógrafo, se idease un artilugio que pudiese reproducir la imagen dinámica de una función teatral y, en nota, apunta que el kinetoscopio de Edison, que avanzaba hacia el cinematógrafo, convertía en realidad este sueño.

Sin embargo, en su renovador proyecto extraña la falta de un lenguaje nuevo, de unos cauces formales coincidentes con tales propósitos. Así, su canto «Al carbón de piedra» se vierte en tercetos encadenados de regusto barroco («Este, que veis, carbón endurecido, / yacer a mantos en terrestre fosa, / rayos de claro sol un tiempo han sido. / A la voz de la Industria poderosa, / abandona, cuál Lázaro, su tumba, / ya más vida resurge esplendorosa [...]» [Palau s. a. (sin año): 
111]). En «El rayo» (1880), en décimas, el tono épico conecta con Quintana. En la oda «A la locomotora» la máquina vuelve a ser monstruo singular: «serpiente férrea y anulosa / que en la cabeza el corazón ostenta», animal nervioso: «corcel ganoso de combate», o conecta con el bestiario clásico: «hipógrifo sin alas», siempre poderoso y bravo, vencedor del huracán y capaz de sortear cualquier accidente geográfico. Se repiten los adjetivos ya notados y las apelaciones al lector. La locomotora es el símbolo de esta edad y es, por ello, comparada con los de otras épocas: es «imagen de la bíblica serpiente», «cual paloma del Arca / es anuncio de paz», «cual caballo de Troya», porque transporta a hombres en su vientre; y ocupa el lugar de los mitos antiguos: «Es del Comercio mensajera activa [...] / sustituye al alípede Mercurio», «Ceres moderna, va sembrando a miles / los prolíficos granos del fomento»... Este «Caballo del progreso» es, al fin, la realización de una quimera que afianza la libertad humana.

Palau aspiró a una poesía nueva y reformada pero, sin embargo, no retocó ni creó un ritmo y una poética adecuadas al cambio de asunto, por lo que -al igual que en los versos de sus compañeros- sus composiciones pierden frescura y nacen un tanto acartonadas y viejas. Sus poemas contribuyen a introducir en el léxico de la poesía algunos términos originales, aunque tampoco aquí hay revoluciones. Él mismo cuenta en su discurso que llevó a cabo con prudencia esta incorporación, prefiriendo, por ejemplo, la palabra «infusorio» a «microbio» porque la segunda no se encontraba en el diccionario de la Real Academia en 1881 (figura en el de 1884). Sí utiliza la voz «fonógrafo», ausente del DRAE hasta 1899; o «ictíneo» (en cursiva en el poema «La Poesía y la Ciencia»), que se introduce en 1925. Su léxico, al igual que sus imágenes, resultan desfasadas con respecto a sus propósitos. Las voces científicas, admite el autor en su discurso, participan de la sequedad y precisión de la ciencia, pero su uso en la literatura va poco a poco dulcificándolas (Palau 1908: 63); las nuevas realidades científicas parecen ajenas a la lírica pero, poco a poco, se irán asimilando a los temas heredados de la tradición: «Hay que dar tiempo al tiempo para que lo moderno consiga tal linaje de belleza», afirma (64), y cree que los hombres pronto adquirirán la sensibilidad moderna que les permita, como a él mismo, admirar «el gigantesco poema metálico denominado Torre de Eiffel». Palau vaticinaba una «forma líricoépica», pero apenas vislumbró su alcance. Es innegable el mérito de su empeño y lo casi profético de su intuición renovadora que, con nuevos vestidos y a partir de una ideología opuesta, enlaza con el manifiesto futurista de Marinetti, publicado sólo un año después de este discurso.

\section{En el «fin de siglo». Conclusiones}

En el capítulo de las conclusiones, creo que hay algo que une todas las composiciones citadas a lo largo del trabajo: el poeta del XIX no parece contemplar nunca directamente el objeto, sino 
que lo hace a través de conceptos abstractos y así los describe y canta. Más que crear nuevas imágenes y metáforas los nombra o describe de forma indirecta a través de cualidades que están fuera del objeto e, incluso, que son más importantes que él mismo: el telégrafo une a los pueblos, el fonógrafo permite el diálogo con el Más Allá, la fotografía sólo capta la materia y no el alma, etc. (etcétera); de tal manera que a veces se observa que los poemas hablan más de la importancia de la fraternidad humana que del objeto mismo, o del amor filial, o de la mayor importancia del espíritu sobre la materia... Los poemas que polemizan sobre el valor de las máquinas y la ciencia, y que muestran su desconfianza ante su creciente poder, están anclados en el valor trascendental de la polémica misma y casi parecen olvidar la nueva realidad que la técnica está creando. Una excepción podría ser la de Joaquín M. ${ }^{a}$ Bartrina, cuyos atrevimientos léxicos le llevan a transcribir el lenguaje científico puro («De omni re scibili»: «¿Hay nada, ¡vive Dios! / bello como la fórmula algebraica / $\mathrm{C}=\pi \mathrm{r}^{2}$ ?», 1939: 105).

Por otro lado, en la mayoría de los textos vistos hasta el momento la principal novedad radica en el tema y, parcialmente, en el vocabulario; no lo son las estrofas, ni la retórica, heredera del verso enfático a lo Quintana y de la poesía clasicista. A partir de estas composiciones podría afirmarse que la remozada épica del siglo XIX descansa en cimientos antiguos y sigue utilizando una expresión altisonante y las más de las veces hueca y tópica, que recurre a un imaginario que resulta caduco aunque esté refiriéndose a nuevas realidades. Aunque algunos autores intentan reinterpretar la mitología y la acercan a las nuevas realidades de la era tecnológica, el lenguaje traiciona sus propósitos. Además, es constante el recuerdo de las épocas gloriosas del pasado español y, en concreto, de la figura de los descubridores; entre todos, de Cristóbal Colón: la gesta americana vuelve a realizarse (o a completarse) ahora gracias al telégrafo y al teléfono, que acercan América y Europa, fomentando una fraternidad desvanecida por la distancia. Los poetas siguen usando un vocabulario igualmente heredado de la tradición quintanesca, que abusa del apostrofe, de las interrogaciones, exclamaciones y apelaciones al lector, y usan expresiones que pronto parecen gastadas: la ciencia es siempre «portentosa» y causa «asombro y pasmo», el tren es «corcel flamígero», «monstruo fiero», el telégrafo, «rayo fugaz»...; se repiten las mismas personificaciones o animalizaciones de los elementos de la naturaleza y de las máquinas (se recurre al león, a la pantera, al águila, la serpiente...); las calificaciones son siempre superlativas; etc. (etcétera) Como en toda epopeya es palmaria la preferencia por el vocabulario bélico y, en la línea de la hipérbole, por los términos que hablan de ardor, fuerza, empuje, arrojo... Las ideas de Palau, ya en los límites finales del siglo, son la concreción teórica más importante del proyecto de una poesía nueva y moderna, que se asimila a los cambios que está experimentando la sociedad industrial y, sin embargo, sigue anclada en el lenguaje poético heredado de la tradición, demostrando un conservadurismo contradictorio con respecto a sus teorías científico-poéticas. Juegos florales y otros certámenes poéticos oficiales (celebrados en torno a estos temas, como antes se vio con el ferrocarril o, ahora, en A la ciencia: Oda, de Ángel Laso de la Vega [1880], ganador de los celebrados en Ferrol con motivo de la inauguración del dique de la Campana) 
favorecen este tono declamatorio y pseudoclásico.

Cuando «Clarín», en su Apolo en Pafos (1887; véase 1988: 31-32), abominaba de la poesía decimonónica en el límite del fin de siglo, considerándola tópica, manida, falta de verdadero aliento lírico, y demandaba un cambio revolucionario para librarla de la muerte total, ataca sobre todo a la poesía quintanesca, que juzga hueca y consumida con sus mismos temas, entre los que cita los cantos al mar, al sol, a Padilla, a Maldonado, «[...] o al inventor del hipo». Entre estos poemas se encontrarían muchos de los citados, a los que se pueden sumar otros procedentes de los primeros libros de poetas de la generación siguiente, que heredan la expresión decimonónica aunque luego la rechacen: por ejemplo, de Rubén Darío (1967: 28) se conserva un poema incompleto titulado «Al Progreso», y también «El libro», de 1882 (idem: 29-55), enlaza con este espíritu. En idéntica línea están «A la invención de la máquina de vapor» y «Al descubrimiento de la electricidad», de Antonio de Zayas (1892: 58-60 y 61-64). Versos similares escriben otros poetas en el Fin de Siglo dentro de la temática de la «lucha», característica de estos años (Ara Torralba 1996) $^{12}$ (40429c3e-45b0-42cd-9bac-b21e9d8e96ca_2.html\#N_12_).

Las imágenes y metáforas más novedosas son escasas, como en los ejemplos precedentes se ha podido advertir, y asoman en el poema «El fonógrafo» de Jackson Veyán (precisamente un autor alejado del tono épico de la poesía civil, la que más utiliza el tema de la ciencia), y en alguna composición, en forma de prosopopeya: «metálicas venas» («La locomotora», de Palau), o los versos citados más arriba de Pérez Barzana en torno al submarino de Peral. Gregorio Torres Nebrera aporta dos ejemplos del poema «A un poeta del porvenir» de Carolina Coronado ( «políglotas vertientes extendimos», para referirse al cable telegráfico submarino, y «arpa eléctrica», para nombrar al tendido telegráfico por hilos) e indica que, en su opinión, «son imágenes que muy bien hubiese podido suscribir un poeta futurista» (1993,1: 489). Se trata siempre de casos aislados y no predominantes.

En definitiva, puede afirmarse que la poesía española de los inicios de la modernidad, anclada en prejuicios y en poéticas desfasadas, si bien intuyó el camino de la poesía futura e impulsó la ampliación de los dominios de la poesía, dejó pasar la oportunidad de una renovación profunda en cuerpo y alma a instancias de las inéditas realidades que aportaba la sociedad industrial. Tal vez la poesía no refleja sino la difícil asunción de la modernidad por parte de una sociedad anclada en viejos valores. Otros vendrían para continuar el camino, pero el impulso casi virginal que podría haber propiciado esa moderna poesía épico-lírica que necesitaba la nueva edad se había perdido para siempre. 


\section{Bibliografía citada}

- Álbum poético a la terminación del ferro-carril de Grao de Valencia a Játiva (1855). Valencia: José Rius.

- ARA TORRALBA, Juan Carlos (1996): Del modernismo castizo: fama y alcance de Ricardo León. Zaragoza: Prensas Universitarias de Zaragoza.

- ARENAL, Concepción (1994): Fábulas en verso originales. Ed. (Edición) de María Cruz García de Enterría. Madrid: Castalia / Instituto de la Mujer.

- ARGULLOL, Rafael (1990): El Héroe y el Único. El espíritu trágico del Romanticismo. Barcelona: Destino.

- BARTRINA, Joaquín M. a (1939): Obras poéticas. Barcelona: Bosch.

- BLANCO-BELMONTE, Marcos Rafael (8 octubre 1903): «El automóvil». En La Ilustración Española y Americana, XXXVII, p. (página) 219.

- - (1906): La vida humilde. Poesías. Madrid: Sáenz de Jubera Hermanos.

- BRIGGS, Asa (dir. (direccción)) (1989): El siglo XIX: Las contradicciones del progreso. Madrid: Alianza.

- BURY, John (1971): La idea de progreso. Madrid: Alianza.

- CAMPILLO, Narciso (1879): «Al siglo XIX. Oda». En: Almanaque de La Ilustración para 1879, pp. (páginas) 115-116.

- CAMPOAMOR, Ramón de (1883): Poética. Madrid: Librería de Victoriano Suárez.

- CANO BALLESTA, Juan (1999): Literatura y tecnología. Las letras españolas ante la revolución industrial (1890-1940). Valencia: Pre-Textos.

- «CLARÍN», Leopoldo Alas (1988): Apolo en Pafos, ed. (edición) de R. F. Sánchez-Alarcos. Almería: Instituto de Estudios Almerienses.

- CORONADO, Carolina (1993): Obra poética, I y II, ed. (edición) de G. Torres Nebrera. Mérida: Editora Regional de Extremadura.

- DARÍO, Rubén (1967): Poesías completas. Ed. (Edición) de A. Méndez Planearte, adiciones de A. Oliver Belmás. Madrid: Aguilar.

- DAUMAS, Maurice (1983): Las grandes etapas del progreso técnico. México: FCE.

- DÍAZ DE ESCOVAR, Narciso (s. a. (sin año)), Efímeras. Málaga: Biblioteca del Eco de Málaga.

- FERNÁNDEZ GRILO, Antonio (1879): Poesías. Madrid: Librería de Fernando Fe.

- — (22 diciembre 1879): «Fotografía iluminada». En: La Ilustración Española y Americana, XLVII, p. (página) 399.

- FERNÁNDEZ RUANO, Manuel (1874): Oda al Canal de Suez. Córdoba: Est. Tip. (Establecimiento Tipográfico) La Actividad.

- FERNÁNDEZ-SHAW, Carlos (1883): Poesías. Madrid: Librería Nacional y Extranjera.

- FERREIRO, Celso Emilio (1973): Curros Enríquez. Madrid: Júcar.

- FOLA IGÚRBIDE, José (1898): La Poesía Moderna. Barcelona: J. Roma, editores. 
- FRIEDMANN, Georges (1977): La crisis del progreso: Esbozo de historia de las ideas (1895-1935). Barcelona: Laia.

- GIL, Ricardo (1931): El último libro (Obras completas. Tomo III). Murcia: Tip. (Tipografía) San Francisco.

- GUTIÉRREZ, Miguel (15 febrero 1887): «Mi siglo. Himno». En: La Ilustración Española y Americana, XL, p. (página) 106.

- GUTIÉRREZ DE ALBA, José María (1890): Alpha y Omega. Trilogía. Madrid: Fernando Fe-Leocadio López (2. ed. (edición)).

- —— (16 abril 1896): «El mundo microscópico. Al eminente sabio Mr. (míster) Pasteur». En: Miscelánea. Revista semanal ilustrada (Sevilla), 14, s. p. (sin paginar)

- HERRANZ, Juan José (28 febrero 1878): «El teléfono». En: La Ilustración Española y Americana, VIII, p. (página) 151.

- JACKSON VEYÁN, José (15 diciembre 1903): «El fonógrafo». En: La Ilustración Española y Americana, XLVI, p. (página) 366.

- LAMARQUE DE NOVOA, José (1895): Poesía líricas. Sevilla, Imp. (Imprenta) de E. Rasco (2. ed. (edición) aumentada).

- LASO DE LA VEGA, Ángel (1880): A la ciencia. Oda. Madrid: Rozas.

- LITVAK, Lily (1980): Transformación industrial y literatura en España (1895-1905). Madrid: Taurus.

- _ (1991): El tiempo de los trenes. El paisaje español en el arte y la literatura del realismo (1849-1918). Barcelona: Ediciones del Serbal.

- LÓPEZ SILVA, José (1898): Chulaperías. Colección de diálogos en verso. Madrid: Imp. (Imprenta) de los Hijos de M. G. Hernández.

- MARTÍNEZ ROMERO, Josefa (1987): José Durbán Orozco (1865-1921). Un poeta almeriense del Novecientos. Almena: Diputación Provincial.

- NIETO-GALÁN, Agustí (2001): Santponç, Monturiol, Isaac Peral. La seducción de la máquina. Vapores, submarinos e inventores. Madrid: Nivola (Novatores, 2).

- NÚÑEZ DE ARCE, Gaspar (1891a): «Prefacio» a Gritos del combate. Poesías. Madrid: Fernando Fe.

- _- (1891b): El vértigo. Madrid: Librería de Mariano Murillo / Librería de Fernando Fe (32. ${ }^{\text {e edición). }}$

- _- (1892): Un idilio y Una elegía. Madrid: Librería de Mariano Murillo.

- —_ (s. a. (sin año)): Miscelánea literaria: cuentos, artículos, relaciones y versos, Barcelona: Maucci.

- ORTIZ DE PINEDO, Manuel (15 noviembre 1878): «La Exposición Universal de París». En: La Ilustración Española y Americana, XLII, pp. (páginas) 286-287.

- PALACIO, Manuel del (25 noviembre 1871): «El túnel de Mont-Cenis». En: La Ilustración Española y Americana, XXXIII, pp. (páginas) 574-575.

- PALAU, Melchor de (s. a. (sin año)): Verdades poéticas. Barcelona: F. Granada y Cía. (Compañía), editores, 6. ${ }^{\text {a }}$ ed. (edición) corregida y aumentada. 
- — (1905): Poesías. Barcelona: Luis Tasso.

- _- (1908): Discursos leídos ante la Real Academia Española en la recepción pública de... Madrid: Tip. (Tipografía) de la Revista de Archivos, Bibliotecas y Museos.

- PALENQUE, Marta (1990): El poeta y el burgués (Poesía y público 1850-1900). Sevilla: Alfar.

- PÉREZ BARZANA, Luis (3889): A Isaac Peral. España con honra. Poema. Madrid: J. Góngora y Álvarez, impresor.

- QUEROL, Vicente Wenceslao (1985): Obras completas, II, ed. (edición) de L. Guarner. Valencia: Conselleria de Cultura, Educació i Ciència de la Generalitat Valenciana.

- REINA, Manuel (22 enero 1881): «El poeta en el siglo XIX». En: La Ilustración Española y Americana, III, pp. (páginas) 54-55.

- REYERO, Carlos (1999): La escultura conmemorativa en España. La edad de oro del monumento público, 1820-1914. Madrid: Cátedra.

- RODRÍGUEZ MARÍN, Francisco (1895): Ciento y un sonetos. Sevilla: Imp. (Imprenta) de E. Rasco.

- RUEDA, Salvador (1993): El ritmo. Ed. (Edición) de M. Palenque. Exeter: University of Exeter Press.

- RUIZ AGUILERA, Ventura (1880): Poesías. Madrid: Biblioteca Universal.

- —_ (s. a. (sin año)): «Prólogo» a Ecos Nacionales y Cantares. Madrid: Imp. (Imprenta) de la Biblioteca de Instrucción y Recreo (4. ${ }^{\mathrm{a}}$ ed. (edición)).

- SELGAS, José (1882): Poesías, II. Madrid: Imp. (Imprenta) A. Pérez Dubrull.

- URRUTIA, Jorge (1995): «Introducción» a Poesía española del siglo XIX. Madrid: Cátedra.

- VELARDE, José (1886): Obras poéticas, I: Poesías y leyendas. Madrid: F. Álvarez / L. P. Villaverde.

- ZAYAS, Antonio de (1892): Poesías. Madrid: Celestino Apodaza.

$\underset{\text { Indice }}{\text { A }}(40429 \mathrm{c} 3 \mathrm{e}-45 \mathrm{~b} 0-42 \mathrm{~cd}-9 \mathrm{bac}-\mathrm{b} 21 \mathrm{e} 9 \mathrm{~d} 8 \mathrm{e} 96 \mathrm{ca} \cdot \mathrm{html})$

Fundación Biblioteca Virtual Miguel de Cervantes

(/fundacion/)
Mapa del sitio (/mapa-web/)

Política de cookies (/cookies/)

Marco legal (/marco-legal/) 